\title{
Self-efficacy in elderly with type 2 Diabetes Mellitus
}

\author{
Autoeficácia em idosos com Diabetes Mellitus tipo 2 \\ Autoeficacia en ancianos con Diabetes Mellitus tipo 2
}

Mariana Campos de Sousa' ORCID: 0000-0001-6803-212X

Bruna Stephanie Sousa Malaquias' ORCID: 0000-0001-9986-6020

Suzel Regina Ribeiro Chavaglia' ORCID: 0000-0001-7033-0185

Rosali Isabel Barduchi OhI" ORCID: 0000-0002-0760-2173

Fabiana Fernandes Silva de Paula"I' ORCID: 0000-0003-2557-9592

Karina Santos da Silva"' ORCID: 0000-0001-8384-8020

Álvaro da Silva Santos' ORCID: 0000-0002-8698-5650

'Universidade Federal do Triângulo Mineiro. Uberaba, Minas Gerais, Brazil.

"Universidade Federal de São Paulo. São Paulo,

São Paulo, Brazil.

III Prefeitura Municipal Uberaba. Uberaba, Minas Gerais, Brazil.

How to cite this article:

Sousa MC, Malaquias BSS, Chavaglia SRR, OhI RIB, Paula FFS, Silva KS, et al. Self-efficacy in elderly with type 2 Diabetes Mellitus. Rev Bras Enferm. 2020;73(Suppl 3):e20180980 doi: http://dx.doi.org/10.1590/0034-7167-2018-0980

Corresponding author:

Mariana Campos de Sousa

E-mail:mariana_camposdesousa@hotmail.com

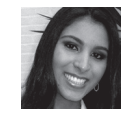

EDITOR IN CHIEF: Dulce Barbosa ASSOCIATE EDITOR: Margarida Vieira

\begin{abstract}
Objective: to analyze the self-efficacy of elderly with type 2 diabetes mellitus and the relationship with sociodemographic, clinical, knowledge, and attitude variables. Method: a cross-sectional quantitative study conducted with 256 elderly people enrolled in Family Health Strategies. Data were obtained through interviews. Descriptive statistical analysis and multiple linear regression model were performed $(p<0.05)$. Results: female, 69.95 -year mean age, white skin color, 4-7 years of schooling, living with a partner, retirees, low individual monthly income, 6 to 15 years of illness, Catholics, living with children (with or without spouse). The elderly's low knowledge and negative attitude prevailed. Self-efficacy was associated with attitude and knowledge in the domains "General and Specific Diet", "Physical Exercise" and "Blood Glucose". Conclusion: self-efficacy investigations in type 2 Diabetes Mellitus management in the elderly are important and encourage treatment adherence. Descriptors: Elderly; Type 2 Diabetes Mellitus; Self-efficacy; Knowledge; Attitude.
\end{abstract}

\section{RESUMO}

Objetivo: analisar a autoeficácia de idosos com Diabetes Mellitus tipo 2 e a relação com as variáveis sociodemográficas, clínicas, de conhecimento e atitude. Método: estudo transversal, quantitativo, realizado com 256 idosos cadastrados em Estratégias Saúde da Família. Obteve-se os dados através de entrevistas. Procedeu-se análise estatística descritiva e modelo de regressão linear múltipla $(p<0,05)$. Resultados: predominou-se sexo feminino, idade média de 69,95 anos, cor da pele branca, 4 a 7 anos de escolaridade, residentes com companheiro, aposentados, baixa renda mensal individual, 6 a 15 anos de doença, católicos, morando com filhos (com ou sem cônjuge). Prevaleceu o baixo conhecimento e atitude negativa dos idosos. A autoeficácia associou-se à atitude e ao conhecimento nos domínios "Nutrição geral e específica”, "Exercício físico" e "Glicose sanguínea". Conclusão: destaca-se a importância de investigações sobre a autoeficácia no manejo do Diabetes Mellitus tipo 2 em idosos no sentido de incentivar a adesão ao tratamento.

Descritores: Idoso; Diabetes Mellitus Tipo 2; Autoeficácia; Conhecimento; Atitude.

\section{RESUMEN}

Objetivo: analizar la auto-eficacia de ancianos con Diabetes Mellitus tipo 2 y la relación con las variables socio-demográficas, clínicos, de conocimiento y actitud. Métodos: estudio transversal, cuantitativo, realizado con 256 ancianos, registrados en Estrategias Salud de la Familia. Los datos fueron obtenidos a través de entrevistas. Se realizó un análisis estadístico descriptivo y un modelo de regresión lineal múltiple $(p<0,05)$. Resultados: se predominó sexo femenino, promedio medio 69,95 años, color de la piel blanca, 4 a 7 años de escolaridad, residentes con compañero, jubilados, baja renta mensual individual, de 6 a 15 años de enfermedad, católicos, viviendo con hijos (con o sin cónyuge). Conclusión: se destaca la importancia de investigaciones sobre la auto-eficacia en el manejo del Diabetes Mellitus tipo 2 en ancianos en el sentido de incentivar la adhesión al tratamiento.

Descriptores: Ancianos; Diabetes Mellitus Tipo 2; Auto-Eficacia; Conocimiento; Actitud. 


\section{INTRODUCTION}

The demographic transition process in Brazil triggered a rapid population aging. The elderly, aged 60 and over, in 2018, represented about 28.1 million Brazilians $(13.4 \%)^{(1)}$. For the state of Minas Gerais, the estimate was nearly 3.2 million elderly in 2018. In Uberaba, it would reach 37,365 elderly, about $11.3 \%$ of the municipality total population ${ }^{(1)}$.

With aging populations and the persistence of unhealthy lifestyles, chronic noncommunicable diseases (NCDs) increase(2), among them type 2 Diabetes Mellitus (2DM). In Brazil, $18.1 \%$ of the elderly population has $2 \mathrm{DM}$; in the Southeast, this proportion increases to $19.5 \%$ and in the state of Minas Gerais, $19.6 \%{ }^{(3)}$.

DM treatment involves periodically monitoring capillary blood sugar, engaging in regular physical activity, adopting a healthy diet, and taking medications when needed ${ }^{(4)}$.

However, not everyone is aware of 2DM and its complications, and the importance of this care for glycemic control and maintenance of quality of life. This lack of knowledge may reflect on the effectiveness of the individual for self-care ${ }^{(5)}$.

Self-efficacy can be defined as the belief of an individual about his ability to perform activities that influence his life, that is, his ability to self-care. These beliefs determine how people feel, think, motivate and behave ${ }^{(6)}$. When taken into the context of 2DM, these activities are related to self-care behaviors, including blood glucose monitoring, dietary control, physical activity, foot care, and medication intake, as recommended ${ }^{(7)}$.

With the aging of the Brazilian population and the increase in the number of NCDs, among them 2DM, there is a need to know this population better. In addition, there is a lack of studies investigating self-efficacy in diabetic elderly, highlighting the importance of knowing how the elderly see their ability to self-care.

\section{OBJECTIVE}

To analyze the self-efficacy of elderly with 2DM and the relationship with sociodemographic, clinical, knowledge, and attitude variables.

\section{METHODS}

\section{Ethical aspects}

The research was authorized by the Health Office of the city of Uberaba, state of Minas Gerais, and approved by the Research Ethics Committee of Universidade Federal do Triângulo Mineiro. The research respected the ethical issues of research involving human beings, defined by the Brazilian National Health Board (Conselho Nacional de Saúde) (Law 466/12). The participation of the elderly occurred after consent and signing of the Free and Informed Consent Term.

\section{Design, period and place of study}

An observational, cross-sectional study with a quantitative approach. The writing of the manuscript was guided by the criteria of the Strengthening the Reporting of Observational Studies in
Epidemiology (STROBE) tool ${ }^{(8)}$. It was performed at the home of the diabetic elderly, registered in Family Health Strategies (FHS) of the urban area of the city of Uberaba from March to June 2018. According to the Municipal Health Office (MHO), Uberaba has 47 FHS in the urban zone, distributed in three health districts, aiming at municipality organization and geographical delimitation ${ }^{(9)}$.

\section{Population and sample; inclusion and exclusion criteria}

The sample size calculation considered a prevalence of $78.0 \%$ drug treatment adherence, as described in the Brazilian literature ${ }^{(10)}$. There was a 5\% accuracy and a 95\% confidence interval for a finite elderly population with $2 \mathrm{DM}$, reaching a sample of 256 subjects.

Considering a $20 \%$ sample loss, the maximum number of interview attempts was 320 . To obtain the sample, a simple random draw was performed in the Statistical Package for Social Sciences (SPSS) version 21 program, with a variable/proportional sample for each FHS according to the number of diabetic elderly in each team, until reaching the total value calculated.

Being 60 years old or older; having 2DM medical diagnosis; being on drug treatment; being registered with the FHS of Uberaba were inclusion criteria. Elderly people who did not reach the minimum score on the Mini-Mental State Examination (MMSE) according to schooling level were excluded; those who had a speech or severe hearing problem, disabling communication during the interview; elderly residents in long-term care facilities and/or not at home on the day and time of visit, after 3 attempts.

\section{Study protocol}

Data collection was performed through interviews at the elderly's house. MMSE, structured sociodemographic and clinical questionnaire, the translated version of Diabetes Knowledge Scale (DKN-A) and Attitudes Questionnaire (ATT-19), Diabetes Management Self-Efficacy Scale (DMSES) for 2DM patients were the tools used.

MMSE was applied at the beginning of the interview for cognitive screening, using the translated and validated version in Brazil, which considers schooling level at the cutoff points for cognitive impairment ${ }^{(11)}$. To characterize the socio-demographic, economic and health data, the sociodemographic and health questionnaire prepared by the authors themselves and based on previous studies was used ${ }^{(12-13)}$.

Knowledge about the disease was measured using the DKN-A questionnaire, which has 15 multiple choice items on different aspects related to general knowledge. Score greater than 8 (eight) indicates greater knowledge about $\mathrm{DM}^{(14)}$. Attitude towards the disease was assessed by ATT-19, which measures DM psychological adjustment. It consists of 19 items, ranging from 19 to 95 points. Score higher than 70 points indicates positive attitude about the disease ${ }^{(15)}$.

Self-efficacy was verified using DMSES, which assesses the ability of the individual with 2DM to perform self-care behaviors regarding this disease. The DMSES scale was translated, adapted and validated into Brazilian Portuguese, obtaining 0.78 as Cronbach's alpha coefficient for the total scale ${ }^{(16-17)}$.

It is a 20-item Likert scale with a score determined by the tool's global mean. Higher means indicate higher self-efficacy ${ }^{(16)}$. 


\section{Analysis of results, and statistics}

Data were statistically analyzed using the SPSS, version 21.0. Descriptive analyzes of the data were performed based on the determination of absolute simple frequencies and percentages for categorical variables and centrality (mean, median, mode) and dispersion measures (standard deviation, minimum and maximum) for quantitative variables. For multivariate analysis, multiple linear regression was used to assess self-efficacy and its relationship with sociodemographic and clinical variables, knowledge and attitudes towards 2DM.

\section{RESULTS}

Of the 256 participants, most were female (61.7\%); 69.95 mean age (SD: 7.02$)$; 4 to 7 years of schooling (40.6\%); lived with a partner (59.0\%); white skin color (51.2\%); Catholic religion (64.5\%).

Regarding individual monthly income, $57.4 \%$ of the elderly reported receiving a minimum wage. Of the monthly family income, $60.5 \%$ had income between one and three minimum wages. Retired elderly (79.7\%) without professional occupation (81.3\%) predominated.

Of the clinical variables, disease duration ranged from 6 to 15 years of diagnosis of 2DM, totaling $41.8 \%$, mean years of diagnosis of 13.87, (SD: 9.51). Regarding lifestyle, $27 \%$ were former smokers and $7.4 \%$ were smokers, $18.4 \%$ consumed alcohol and $8.6 \%$ were former alcoholics, and $68.4 \%$ did not practice physical activity. Regarding the medication used to control blood glucose, most elderly reported using only oral drugs for 2DM treatment (74.6\%), while $17.6 \%$ were associated oral medication with insulin.

Regarding the total knowledge score assessed by DKN-A, it was found that $60.9 \%$ of the elderly had low knowledge about 2DM ( $<8$ points). Regarding the total score obtained by ATT-19, negative attitude ( $<70$ points) was found in most of the interviewees (75.8\%) (Table 1).

Data obtained by DMSES stated that the domain "General Diet and Drug Treatment" had the highest mean, 4.11 points (SD: 0.58). The domain "Physical Exercise" had the lowest mean, 2.83 points (SD: 1.38). The mean total score value of the scale was 3.75 (SD: 0.59) (Table 2).

Table 3 presents the multiple linear regression model for total score and self-efficacy domains for DM.

The total self-efficacy score was associated with attitude $(p=<0.001)$ and knowledge $(p=<0.001)$. "Specific Diet and Weight" was associated with attitude $(p=0.0006)$. "General Diet and Drug Treatment" was associated with attitude $(p=0.032)$ and knowledge $(p=<0.001)$. "Physical Exercise" was associated with family income $(p=0.020)$, schooling $(p=0.010)$ and attitude $(p=<0,001)$. "Blood Glucose" was associated with 2DM time $(p=0.029)$ and knowledge $(p=<0.001)$.

Table 1- Distribution of measures of central tendency related to knowledge and attitude of elderly with type 2 Diabetes Mellitus, Uberaba, Minas Gerais, Brazil, 2018

\begin{tabular}{|c|c|c|c|c|c|c|c|}
\hline Variables & n (\%) & Minimum & Maximum & Mean & SD & Median & Cronbach's alpha \\
\hline $\begin{array}{l}\text { Knowledge total score (DKN-A) } \\
\text { Low knowledge } \\
\text { High knowledge }\end{array}$ & $\begin{array}{l}156(60.9) \\
100(39.1)\end{array}$ & 0 & 14 & 7.62 & 2.74 & 8 & 0.62 \\
\hline $\begin{array}{l}\text { Attitude total score (ATT-19) } \\
\text { Negative attitude } \\
\text { Positive attitude }\end{array}$ & $\begin{array}{c}194(75.8) \\
62(24.2)\end{array}$ & 43 & 89 & 64.43 & 8.81 & 65 & 0.75 \\
\hline
\end{tabular}

Table 2- Distribution of central tendency measures of self-efficacy domain scores in elderly with type 2 Diabetes Mellitus, Uberaba, Minas Gerais, Brazil, 2018

\begin{tabular}{|c|c|c|c|c|c|c|}
\hline Self-efficacy & Minimum & Maximum & Mean & SD & Median & Cronbach's alpha \\
\hline Self-efficacy mean total score (DMSES) & 1.45 & 5.00 & 3.75 & 0.59 & 3.75 & 0.82 \\
\hline Specific Diet and Weight & 1.00 & 5.00 & 3.77 & 0.93 & 4.00 & 0.81 \\
\hline General Diet and Drug Treatment & 1.89 & 5.00 & 4.11 & 0.58 & 4.11 & 0.68 \\
\hline Physical Exercise & 1.00 & 5.00 & 2.83 & 1.38 & 3.00 & 0.87 \\
\hline Blood Glucose & 1.00 & 5.00 & 3.53 & 1.08 & 3.67 & 0.76 \\
\hline
\end{tabular}

Table 3- Multiple linear regression coefficients for total score and self-efficacy domains of elderly with type 2 Diabetes Mellitus, Uberaba, Minas Gerais, Brazil, 2018

\begin{tabular}{|c|c|c|c|c|c|c|c|c|c|c|}
\hline \multirow[t]{2}{*}{ Variables } & \multicolumn{2}{|c|}{$\begin{array}{l}\text { Specific Diet } \\
\text { and Weight }\end{array}$} & \multicolumn{2}{|c|}{$\begin{array}{l}\text { General Diet and } \\
\text { Drug Treatment }\end{array}$} & \multicolumn{2}{|c|}{ Physical Exercise } & \multicolumn{2}{|c|}{ Blood Glucose } & \multicolumn{2}{|c|}{ Total Score } \\
\hline & B & $p^{*}$ & $\boldsymbol{\beta}$ & $p^{*}$ & B & $p^{*}$ & B & $p^{*}$ & $\boldsymbol{\beta}$ & $p^{*}$ \\
\hline Sex & -0.013 & 0.833 & 0.055 & 0.365 & 0.121 & 0.051 & 0.089 & 0.138 & 0.085 & 0.151 \\
\hline Age group & 0.071 & 0.257 & -0.061 & 0.319 & 0.011 & 0.854 & 0.114 & 0.058 & 0.036 & 0.544 \\
\hline Family income & 0.117 & 0.072 & 0.066 & 0.297 & -0.149 & 0.020 & -0.051 & 0.413 & 0.009 & 0.884 \\
\hline Schooling & -0.028 & 0.680 & 0.042 & 0.524 & 0.170 & 0.010 & 0.057 & 0.380 & 0.082 & 0.197 \\
\hline Disease time & -0.005 & 0.941 & 0.018 & 0.766 & -0.005 & 0.935 & 0.131 & 0.029 & 0.040 & 0.498 \\
\hline Knowledge & 0.098 & 0.141 & 0.268 & $<0.001$ & -0.006 & 0.922 & 0.289 & $<0.001$ & 0.233 & $<0.001$ \\
\hline Attitude & 0.177 & 0.006 & 0.135 & 0.032 & 0.269 & $<0.001$ & 0.060 & 0.331 & 0.238 & $<0.001$ \\
\hline
\end{tabular}




\section{DISCUSSION}

The profile of the elderly with 2DM in this study is similar to that found in other Brazilian and international studies that describe the predominance of female elderly, between 60 and 69 years old, low schooling level and individual income of one minimum wage ${ }^{(18-21)}$.

A study conducted in a city in the state of Sergipe with 55 adult subjects with 2DM identified that most of the people investigated had lower scores on the glycemic control self-efficacy scale, related to lack of access to the glucometer and low-income reagent strips. It can be inferred that such data corroborates the findings of this research by identifying the existence of a statistically significant association between income and self-efficacy ${ }^{(22)}$.

Related to the mean time of diagnosis of 2DM, Brazilian studies differed from the present study (13.87 years), indicating a diagnosis time less than five years ${ }^{(21,23-24)}$. A study conducted in the city of Montes Claros, state of Minas Gerais found that $38.4 \%$ of respondents had a diagnosis of 2DM between 8 and 15 years old ${ }^{(18)}$.

Older people with longer diagnosis of 2DM are more prone to poor glycemic control and quality of life; to have higher rates of complications resulting from the disease; and need for insulin to control blood glucose ${ }^{(25)}$. Insulin use may reflect negatively on self-efficacy due to timing of application and appropriate dosages, discomfort, fear of hypoglycemia and interference with daily activities ${ }^{(10)}$.

Regarding lifestyle, Brazilian investigations presented similar results to this study. A study conducted in the city of Campinas, state of São Paulo showed that $65.6 \%$ of the diabetic elderly were not smokers and $78.8 \%$ did not drink alcohol ${ }^{(26)}$. Another study conducted in the city of Criciuma, state of Santa Catarina with adults and seniors with hypertension and DM found that $79.4 \%$ of participants did not practice physical activity ${ }^{(27)}$. Another study found that only $38.7 \%$ of older diabetics practiced physical activity regularly ${ }^{(11)}$.

Lifestyle changes should be part of NCD treatment, but lifestyle habits are often difficult to change ${ }^{(11)}$. In this sense, health professionals need to work with health education, with the elderly in a differentiated and individualized way, encouraging autonomy and favoring self-care and treatment adherence ${ }^{(28)}$.

As for the knowledge of the elderly about DM, a study conducted in Uberaba corroborates the present research, in which, from the use of the DKN-A scale, low knowledge prevailed. Performed with diabetic elderly, this research observed a variation of 0 to 15 points, and the mean score was 6.35 points, indicating little knowledge about 2DM(21).

Knowledge is fundamental for effective control of DM, as it allows the individual to play an active and cooperative role in the planning and therapeutic follow-up, favoring conscious and healthy decisions ${ }^{(29)}$.

Assessment of a person's knowledge about their illness becomes important for identifying the beliefs and resources involved. It provides an effective and individual treatment plan, and provides guidance to practitioners on approaches to health education and consultation, emphasizing existing knowledge and providing patients with new information ${ }^{(29)}$.

Concerning attitude, in the present study there was a prevalence of negative attitude, a result similar to other Brazilian studies. In a study with diabetic elderly in Uberaba, which also used the ATT-19, a score ranging from 35 to 85 points was found, with an mean of 63.23 points, which indicates a negative attitude towards $2 \mathrm{DM}^{(21)}$.

Attitude is a concept understood as the likelihood that an individual will adhere to and maintain certain patterns of behavior. It can be taught and learned in the same way as it is influenced by cognitive, motivational and emotional components ${ }^{(30)}$.

Thus, for professionals to be able to develop a positive attitude in users with 2DM, it is necessary to assess the degree of motivation and emotional aspects of the elderly, to know where they can intervene, encouraging the change of behavior, thoughts and attitudes.

Regarding the relationship between knowledge and attitude, knowledge proved to be one of the variables that can influence the individual's attitudes towards DM management. However, it is not always sufficient to promote the necessary changes in the attitude of patients. Other components may be essential to this process, such as motivational, emotional and social aspects and should be investigated ${ }^{(31)}$.

In this sense, care provided by a multidisciplinary health team can provide with support needs that people with 2DM need, through motivation, established bonds, leading to changes in attitude that will allow better adherence and appropriate management of the disease. Positive attitudes are closely related to improved self-care and better coping with the disease ${ }^{(31)}$.

Self-efficacy, as a tool to promote self-care practices, is an important ally for health professionals, especially in primary care, assisting in treatment adherence, coping with the disease and empowering self-care of 2DM users.

The present study showed a moderately high mean selfefficacy score (3.75) and respondents were more self-effective in activities related to medication intake and general diet, and less self-effective in physical exercise.

These results were similar to the study conducted in Malaysia with adults and elderly people with 2DM using the DMSES scale. DMSES obtained a total mean self-efficacy score of 7.33 (SD \pm 2.25 ), with the maximum mean score being $10^{(7)}$. The domain with the highest score was 'medications and follow-up' (8.78, SD \pm 1.76$)$ and the lowest score was 'blood glucose monitoring' (6.60, SD \pm 2.97). different from those found in this research.

The higher self-efficacy for medication intake can be explained by the fact that this is a task that does not require much effort to be performed ${ }^{(7)}$, unlike physical exercise, which requires discipline, physical effort and persistence.

A study conducted in Iran with 187 diabetic patients had a mean total self-efficacy score of 96.6 (SD \pm 34.6) from the application of DMSES among other scales, indicating low self-efficacy for the development of 2DM self-care ${ }^{(32)}$.

The above study indicates that self-efficacy is the most important predictor of DM self-care and states that the use of self-efficacy theory in designing the necessary patient education interventions could increase 2DM self-care. It is essential for practitioners to assess patient health knowledge levels so that they can tailor health-related information specific to a knowledge domain. Such actions would make patients informed and promote their empowerment ${ }^{(32)}$.

Given this, it can be observed that self-efficacy is a determining factor in adherence to 2DM treatment. Individuals with low 
self-efficacy tend to abandon treatment due to any obstacle because they do not believe in their ability to self-care. In this sense, nursing professionals'actions with these people should be directed towards achieving autonomy, seeking to empower them for selfcare. They can be developed through health education activities, use of active methodologies and through nursing consultations ${ }^{(32)}$.

There was a statistically significant association between the total self-efficacy score and the domain "General Diet and Drug Treatment" with the variables knowledge $(p=<0.001)$ and attitude $(p=<0.001)$.

Thus, it is observed that knowledge related to 2DM and the positive attitude towards the disease favor the adequacy of food and the follow-up of drug therapy, which represents a better treatment adherence.

A qualitative study conducted in the south of the country with elderly diabetics, identified factors that may provide or hinder adherence to drug treatment and healthy eating. Among the factors facilitating adherence were preexisting healthy habits, family support, access to medicines, and concern for complications. Among the factors that hinder adherence, family-related issues (lack of support, understanding) were identified, generating feelings such as sadness and loneliness, high cost of healthy food, medications and consultations with professionals, and the non-acceptance or non-recognition of the risks of complications arising from the disease ${ }^{(33)}$.

Lack of knowledge can prevent change in human behavior. However, self-efficacy beliefs are also important for behavioral changes in health to occur. People who firmly believe in their ability to perform self-care are more likely to develop skills and competences to achieve their goals ${ }^{(34-35)}$.

It was found that "Specific Diet and Weight" and "Physical Exercise" were associated with the attitude, however knowledge was not significant. This result allows us to understand that, although the individual knows the disease, knows about the necessary treatment and its complications, may not follow the recommendations related to the specific diet for 2DM and exercise. This makes it difficult to reduce weight and control blood glucose. People with positive attitudes are more likely to follow these guidelines because they can cope with the disease and self-care, and are motivated to change inappropriate behaviors ${ }^{(35-36)}$.

In the present research, an association was found between "Physical Exercise" and family income. The lower the income, the better the self-efficacy for physical exercise. Walking is a basic physical activity that is easy to perform and has no cost to the person, so individuals with lower incomes can engage in this practice more often ${ }^{(37)}$.

On the other hand, people with better incomes usually perform physical exercises in supervised gyms. This requires a person's commitment to go to the place, time devoted to locomotion and activity, which can make it difficult to adhere to this type of physical activity.

Diverging from the present investigation, a study conducted in the city of Ribeirão Preto, state of São Paulo showed that the higher the individual's physical fitness, the higher the per capita family income $(p<0.05)^{(38)}$. This data may be related to the possibility of adequate diet, specific medication, among others to acquire healthy lifestyle habits.
Regarding schooling, a study conducted in Malaysia showed a significantly higher level of self-efficacy among those with secondary education compared to those with elementary education $(p=0.012)^{(39)}$. Another study of diabetic individuals in Iran found a positive correlation between schooling and selfefficacy $(F=6.6, p<0.001)^{(32)}$. Longer schooling time allows the individual to have more conditions and opportunities to seek information about the disease, be more aware ${ }^{(32,39)}$, understand the types of treatments and learn to take care of their own health more easily.

According to time since diagnosis of 2DM, international research results differ from the present study. A survey conducted in Iran found a significant negative correlation between disease duration and self-efficacy, that is, people with long duration of 2DM had lower self-efficacy. This may be due to the fact that, over time, patients become more tired and without expectation of disease control, and thus their self-efficacy also decreases ${ }^{(40)}$.

Another study of people with 2DM in Iran found a significant positive correlation between 2DM time $(r=0.26, p<0.001)$ and self-efficacy. This study corroborates the association of 2DM diagnosis time with "Blood Glucose", which suggests that the longer the diagnosis time, the better the self-efficacy for blood glucose control and monitoring. DM long time causes the individual to acquire knowledge and skills to check blood glucose, and realize that this behavior is essential for quality of life $\mathrm{e}^{(32)}$.

Given this, it is important that DM education activities include some psychosocial factors, such as user self-efficacy, to arouse a significant effect on patient adherence to self-care behaviors and lifestyle changes ${ }^{(32)}$. Knowledge alone is not enough to promote these modifications.

In health education activities, it is important to have a combination of group and individual actions, highlighting home visits ${ }^{(41)}$, which allow the professional to work with the user, on a daily basis. This involvement enables professionals to know the population with whom they work, monitor the difficulties encountered and reach as many elderly people as possible, promoting better knowledge, attitudes, self-care and treatment adherence, as well as providing with changes in lifestyle.

\section{Study limitations}

It is noteworthy that in the literature there is still a scarcity of similar studies addressing the relationship between self-efficacy, knowledge and attitude of elderly with 2DM at home.

The present study also had as limitation the cross-sectional design, which did not allow to establish an association between cause and effect, the scarcity of studies that assess self-efficacy in their different domains and their relationship with the variables of interest of this research.

\section{Contributions to nursing, health or public policy}

Health education activities are important attributions of nurses and other professionals who work with people with 2DM, as they allow them to guide users on health care, encouraging the change of inappropriate habits and treatment adherence. Adopting a healthy and quality lifestyle is important for 2DM treatment, and 
is it necessary that both older people and individuals in general be aware of the need for these changes for them.

The findings of this research reveal the importance of investigating self-efficacy in 2DM management in the elderly and strengthening these measures in primary care, in order to encourage treatment adherence and improve glycemic control. Future research is suggested to investigate further the relationship of self-efficacy, knowledge, and attitude.

\section{CONCLUSIONS}

In the present research, elderly people with women 2DM; aged 60 to 69 years; with 4 to 7 years of schooling; living with a partner; with white skin; Catholic; living with children (with or without spouse); with individual monthly income of one minimum wage and family monthly income of one to three minimum wages; retired and without professional occupation were predominant. Regarding clinical variables, there was a predominance of elderly with 6 to 15 years of diagnosis of 2DM, non-smokers, non-alcoholics and non-practitioners of physical activity.
For self-efficacy, the domain with the highest mean was"General Diet and Drug Treatment" and the domain with the lowest mean was "Physical Exercise".

Regarding knowledge and attitude, there was a predominance of elderly people with low knowledge and negative attitude.

Self-efficacy was associated with attitude and knowledge. "Specific Diet and Weight" was associated only with attitude. "General Diet and Drug Treatment" remained associated with attitude and knowledge. "Physical Exercise" was associated with family income, schooling and attitude. "Blood Glucose" was associated with time of disease and knowledge.

Thus, this study can help health professionals in interventions with the elderly, aimed at preventing diseases and improving self-care.

\section{FUNDING}

This work was carried out with the support of Coordination for Higher Education Personnel Improvement (CAPES - Coordenação de Aperfeiçoamento de Pessoal de Nível Superior) - Financing Code 001.

\section{REFERENCES}

1. Instituto Brasileiro de Geografia e Estatística (IBGE). Projeção da população do Brasil e Unidades da Federação por sexo e idade para o período 2010-2060 [Internet]. Diretoria de Pesquisas. Coordenação de População e Indicadores Sociais. Gerência de Estudos e Análises da Dinâmica Demográfica. Rio de Janeiro: IBGE, 2018 [cited 2018 Nov 10]. Available from: https://www.ibge.gov.br/estatisticas-novoportal/ sociais/populacao/9109-projecao-da-populacao.html?=\&t=downloads

2. Ribeiro JP, Rocha SA, Popim RC. Compreendendo o significado de qualidade de vida segundo idosos portadores de diabetes mellitus tipo II. Esc Anna Nery. 2010;14(4):765-71. doi: 10.1590/S1414-81452010000400016

3. Instituto Brasileiro de Geografia e Estatística (IBGE). Pesquisa nacional de saúde, 2013: percepção do estado de saúde, estilos de vida e doenças crônicas: Brasil, grandes regiões e unidades da Federação [Internet]. Rio de Janeiro: IBGE, 2014 [cited 2018 Nov 10]. Available from: ftp://ftp.ibge.gov.br/PNS/2013/pns2013.pdf

4. Ministério da Saúde (BR). Secretaria de Atenção à Saúde. Departamento de Atenção Básica Estratégias para o cuidado da pessoa com doença crônica: diabetes mellitus. Brasília: MS, 2013 [cited 2018 Nov 10]. (Cadernos de Atenção Básica, n. 36). Available from: http://bvsms. saude.gov.br/bvs/publicacoes/estrategias_cuidado_doenca_cronica_diabetes_mellitus.pdf

5. Kueh YC, Morris T, Ismail AAS. Diabetes knowledge, attitudes, self-management, and quality of life among people with Type 2 Diabetes Mellitus: a comparison between Australia - and Malaysia - based samples. Pertanika J Sci Technol[Internet]. 2017 [cited 2018 Nov 10];25(1). Available from: http://www.pertanika.upm.edu.my/Pertanika\%2OPAPERS/JST\%20Vol.\%2025\%20(1)\%20Jan.\%202017/09\%20JST\%20Vol\%20 25\%20(1)\%20Jan\%20\%202017_0597-2016_pg121-138.pdf

6. Bandura A. Self-efficacy [Internet]. In: Ramachaudran VS (Ed.), Encyclopedia of human behavior, 4: 71-8, New York: Academic Press, 1994 [cited 2018 Nov 10]. Available from: https://www.uky.edu/ eushe2/Bandura/Bandura1994EHB.pdf

7. Tharek Z, Ramli AS, Whitfor, DL, Ismail Z, Mohd Zulkifli M, Ahmad Sharoni SK, et al. Relationship between self-efficacy, self-care behaviour and glycaemic control among patients with type 2 diabetes mellitus in the Malaysian primary care setting. BMC Fam Pract. 2018;19(39). doi: $10.1186 / \mathrm{s} 12875-018-0725-6$

8. Von Elm E, Altman DG, Egger M, Pocock SJ, Gøtzsche PC, Vandenbroucke JP, STROBE Initiative. The Strengthening the Reporting of Observational Studies in Epidemiology (STROBE) statement: guidelines for reporting observational studies. J Clin Epidemiol. 2008;61(4):3449. doi: 10.1016/j.jclinepi.2007.11.008

9. Prefeitura Municipal de Uberaba (MG). Secretaria Municipal de Saúde. Plano municipal de saúde 2018/2021 [Internet]. Uberaba, 2017 [cited 2018 Nov 10]. Available from: http://www.uberaba.mg.gov.br/portal/acervo//saude/arquivos/2017/Plano\%20Municipal\%20de\%20 Saude\%202018-2021\%20 aprovado\%20pelo\%20CMS.pdf

10. Borba AKOT, Marques APO, Ramos VP, Leal MCC, Arruda IKG, Ramos RSPS. Factors associated with elderly diabetic adherence to treatment in primary health care. Ciênc Saúde Coletiva. 2018;23(3):953-61. doi: 10.1590/1413-81232018233.03722016

11. Bertolucci PHF, Brucki SMD, Campacci SR, Juliano Y. O Mini-Exame do Estado Mental em uma população geral: impacto da escolaridade. Arq Neuro-Psiquiatr. 1994;52(1):01-07. doi: 10.1590/S0004-282X1994000100001

12. Santos AS, Silveira RE, Sousa MC, Monteiro T, Silvano CM. Perfil de saúde de idosos residentes em um município do interior mineiro. Rev 
Enferm Atenç Saúde[Internet]. 2012 [cited 2018 Nov 10];1(1). Available from: http://seer.uftm.edu.br/revistaeletronica/index.php/enfer/ article/view/300/280

13. Santos AS, Viana DA, Sousa MC, Meneguci J, Silveira RE, Silvano CM, et al. Atividade física, álcool e tabaco entre idosos. Refacs [Internet]. 2014 [cited 2018 Nov 10];2(1):06-13. Available from: http://seer.uftm.edu.br/revistaeletronica/index.php/refacs/article/view/1142/996

14. Beeney LJ, Dunn SM, Welch G. Measurement of diabetes knowledge: the development of the DKN scales [Internet]. In: Bradley C (ed.). Handbook of psychology and diabetes. Amsterdam: Harwood Academic Publishers, 2001 [cited 2018 Nov 10];159-89. Available from: https:// books.google.com.br/books?id=PAk3KZuG4PIC\&printsec=frontcover\&hl=pt-BR\& source =gbs_ge_summary_r\&cad=0\#v=onepage\&q\&f=false

15. Torres HC, Hortale VA, Schall VT. Validação dos questionários de conhecimento (DKN-A) e atitude (ATT-19) de Diabetes Mellitus. Rev Saúde Pública [Internet]. 2005 [cited 2018 Nov 10];39(6):906-11. Available from: http://www.scielo.br/pdf/rsp/v39n6/26984.pdf

16. Van Der Bijl JJ, Van Poelgeest-Eeltink A, Shortridge- Bagget L. The psychometric properties of the diabetes management self-efficacy scale for patients with type 2 diabetes mellitus. J Adv Nurs. 1999;30(2):352-9. doi: 10.1046/j.1365-2648.1999.01077.x

17. Pace AE, Gomes LC, Bertolin DC, Loureiro HMAM, Van Der Bijl J, Shortridge-Bagget LM. Adaptação e validação da Diabetes Management Self-efficacy Scale para a língua portuguesa do Brasil. Rev Latino-Am Enfermagem. 2017;25 2861. doi: 10.1590/1518-8345.1543.2861

18. Alves ECS, Souza LPS, Alves WS, Oliveira MKS, Yoshitome AY, Gamba MA. Condiciones de salud y funcionalidad de ancianos con Diabetes Mellitus tipo 2 en Atención Primaria. Enferm Glob [Internet]. 2014 [cited 2018 Nov 17];13(34):1-18. Available from: http://scielo.isciii.es/pdf/ eg/v13n34/clinica1.pdf

19. Eknithiset R, Samrongthong R, Kumar R. Factors associated with knowledge, perception, and practice toward self-care among elderly patients suffering from Type 2 diabetes mellitus in rural Thailand. J Ayub Med Coll Abbottabad [Internet]. 2018 [cited 2018 Nov 17];30(1):107-10. Available from: http://jamc.ayubmed.edu.pk/index.php/jamc/article/view/3488/1869

20. Ramos RSPS, Marques APO, Ramos VP, Borba AKOT, Aguiar AMA, Leal MCC. Factors associated with diabetes among the elderly receiving care at a specialized gerontology-geriatric outpatient clinic. Rev Bras Geriatr Gerontol. 2017;20(3):364-74. doi: $10.1590 / 1981-22562017020.160145$

21. Sousa MC, Dias FA, Nascimento JS, Tavares DMS. Correlation of quality of life with knowledge and attitude of diabetic elderly. Investig Educ Enferm. 2016;34(1):180-8. doi: 10.17533/udea.iee.v34n1a20

22. Santos CMJ, Faro A. Self-efficacy, locus of control and adherence to treatment in patients with type 2 diabetes. Rev SBPH [Internet]. 2018 [cited 2019 May 16];21(1):74-91. Available from: http://pepsic.bvsalud.org/pdf/rsbph/v21n1/v21n1a05.pdf

23. Amorim TC, Burgos MGPA, Cabral PC. Perfil clínico e antropométrico de pacientes idosos com diabetes mellitus tipo 2 atendidos em ambulatório. Sci Med. 2017;27(3):ID26616. doi: 10.15448/1980-6108.2017.3.26616

24. Silva AP, Pureza DY, Landre CB. Frailty syndrome in elderly patients with type 2 diabetes mellitus. Acta Paul Enferm. 2015;28(6):503-9. doi: 10.1590/1982-0194201500085

25. Huang ES, Laiteerapong N, Liu JY, John PM, Moffet HH, Karter AJ. Rates of complications and mortality in older patients with diabetes mellitus: the diabetes and aging study. JAMA Intern Med. 2014;174(2):251-8. doi: 10.1001/jamainternmed.2013.12956

26. Prado MAMB, Francisco PMSB, Barros MB. A. Diabetes in the elderly: drug use and the risk of drug interaction. Ciênc Saúde Coletiva. 2016;21(11):3447-58. doi: 10.1590/1413-812320152111.24462015

27. Mazzuchello FR, Tuon L, Simões PW, Mazon J, Dagostin VS, Tomasi CD, et al. Knowledge, attitudes and adherence to treatment in individuals with hypertension and diabetes mellitus. Mundo Saúde. 2016;40(4):418-32. doi: 10.15343/0104-7809.20164004418432

28. Carvalho SL, Ferreira MA, Medeiros JMP, Queiroga ACF, Moreira TR, Negreiros FDS. Conversation map: an educational strategy in the care of elderly people with diabetes mellitus. Rev Bras Enferm. 2018;71(Suppl 2):925-9. doi: 10.1590/0034-7167-2017-0064

29. Sousa MR, McIntyre T, Martins T, Silva E. Questionário dos Conhecimentos da Diabetes (QCD): propriedades psicométricas. Rev Port Saúde Pública. 2015;33(1):33-41. doi: 10.1016/j.rpsp.2014.07.002

30. Rodrigues FFL, Santos MA, Teixeira CRS, Gonela JT, Zanetti ML. Relationship between knowledge, attitude, education and duration of disease in individuals with diabetes mellitus. Acta Paul Enferm. 2012;25(2):284-90. doi: 10.1590/S0103-21002012000200020

31. Oliveira KCS, Zanetti ML. Knowledge and attitudes of patients with diabetes mellitus in a primary health care system. Rev Esc Enferm USP. 2011;45(4):862-8. doi: 10.1590/S0080-62342011000400010

32. Reisi M, Mostafavi F, Javadzade H, Mahaki B, Tavassoli E, Sharifirad G. Impact of health literacy, self-efficacy, and outcome expectations on adherence to self-care behaviors in Iranians with Type 2 Diabetes. Oman Med J. 2016;31(1):52-9. doi: 10.5001/omj.2016.10

33. Campos TSP, Silva DMGV, Romanoski PJ, Ferreira C, Rocha FL. Factors associated with adherence to treatment of people with diabetes mellitus assisted by primary health care. J Health Biol Sci. 2016;4(4):251-6. doi: 10.12662/2317-3076jhbs.v4i4.1030.p.251-256.2016

34. Bandura A. Health promotion by social cognitive means. Health Educ Behav. 2004;31(2):143-64. doi: 10.1177/1090198104263660

35. Bandura A, Azzi RG, Polydoro S. Teoria Social Cognitiva: conceitos básicos. Porto Alegre: Artmed; 2008.

36. Assunção SC, Fonseca AP, Silveira MF, Caldeira AP, Pinho L. Knowledge and attitude of patients with diabetes mellitus in Primary Health Care. Esc Anna Nery. 2017;21(4):e20170208. doi: 10.1590/2177-9465-ean-2017-0208

37. Kelly P, Kahlmeier S, Götschi T, Orsini N, Richards J, Roberts N, et al. Systematic review and meta-analysis of reduction in all-cause mortality from walking and cycling and shape of dose response relationship. Int J Behav Nutr Phys Act. 2014; 11(132). doi: 10.1186/s12966-014-0132-x 
38. Trapé AA, Marques RFR, Lizzi EAS, Yoshimura FE, Franco LJ, Zago AS. Association between demographic and socioeconomic conditions with exercise practice and physical fitness in community projects participants aged 50 years or more in Ribeirão Preto, São Paulo. Rev. bras. Epidemiol. 2017;20(2):355-67. doi: 10.1590/1980-5497201700020015

39. Devarajooh C, Chinna K. Depression, distress and self-efficacy: The impact on diabetes self-care practices. PLoS ONE. 2017;12(3): e0175096. Available from: 10.1371/journal.pone.0175096

40. Dehghan, H, Charkazi A, Kouchaki1 GM, Zadeh BP, Dehghan BA, Matlabi M, et al. General self-efficacy and diabetes management self-efficacy of diabetic patients referred to diabetes clinic of Aq Qala, North of Iran. J Diabetes Metabol Dis. 2017;16(8). doi: 10.1186/ s40200-016-0285-z

41. Teston EF, Spigolon DN, Maran E, Santos AL, Matsuda LM, Marcon SS. Nurses' perspective on health education in Diabetes Mellitus Care. Rev Bras Enferm. 2018;71(Suppl 6):2735-42. doi: 10.1590/0034-7167-2018-0396 